\title{
Feminism Ain't Funny: Woman as “Fun-Killer," Mother as Monster in the American Sitcom
}

\author{
Jack Simmons ${ }^{1}$, Leigh E. Rich ${ }^{2}$ \\ ${ }^{1}$ Department of Languages, Literature and Philosophy, Armstrong Atlantic State University, Savannah, USA \\ ${ }^{2}$ Department of Health Sciences, Armstrong Atlantic State University, Savannah, USA \\ Email: Leigh.Rich@armstrong.edu \\ Received February $1^{\text {st }}, 2013$; revised March $2^{\text {nd }}, 2013$; accepted March $10^{\text {th }}, 2013$
}

\begin{abstract}
Whether America has realized President Herbert Hoover's 20th-century vision of a "chicken in every pot", there is a television in nearly every home. Powerful and accessible, television programs, whether explicitly, convey values and messages to viewers and, thus, can play a role in reifying the status quo or affecting social change. Given comedy programming's roots in radio and Vaudeville, it is no surprise that a recurrent theme in situational comedies is the "war between the sexes". Despite a surfeit of studies examining specific programs, however, there exists no comprehensive project exploring how gender depictions have changed since television's proliferation in post-WWII America. This time span is especially important because it is bisected by second wave feminism. Regarding gender, TV shows need not fortify traditional ideals. But how far has television come? Findings from a pilot study employing a Grounded Theory analysis of selected US sitcoms from 1952 to 2004 suggest that, regardless of the progressive nature of some programming, the most-watched sitcoms reaffirm mainstream stereotypes of women. What has changed, however, is the hierarchical relationship between the sexes. While sitcoms have modified roles of women in an effort to keep up with changing social norms, they have failed to meaningfully alter traditional masculine narratives. What has been won is a superficial role reversal: Where once television women were childlike subordinates to their male counterparts, now men are depicted as irresponsible children women must mother and discipline.
\end{abstract}

Keywords: Television; Situational Comedy; Feminism; Representations of Women; Gender Roles; Pleasure; Motherhood; Role Reversal; United States

\section{The "Family Hour"}

"Three things have been difficult to tame. The ocean, fools, and women. We may soon be able to tame the ocean, but fools and women will take a little longer"". -Vice President Spiro Agnew on the Women's Strike for Equality, August 26, 1970.

"Men want to have fun and wives want to walk that fun deep into the woods and shoot it dead".

-Husband Eddie Stamm in 'til Death, September 7, 2006.

In 1951, I Love Lucy introduced American audiences to Lucy Ricardo, "a talentless housewife ever hopeful of breaking into showbiz" (McNeill, 1996: p. 401). While Mrs. Ricardo's star-studded dreams only amounted to funny fiascos, it would not take long for comedienne Lucille Ball to succeed where her most celebrated character always failed. In the 1952-53 television season, I Love Lucy became the "first smash hit situation comedy", earning the highest average seasonal Nielsen ratings and the distinction of America's most-watched program, an honor it would comfortably hold for four of its six years. In 1952-53, the wacky would-be redhead also became America's most-watched mother. Ball's real-life pregnancy drove the show's second season storyline, and more than 10 million

\footnotetext{
${ }^{1}$ Quoted in an ABC News broadcast by anchorman Howard K. Smith (Douglas, 1995: p. 163)

${ }^{2}$ In this pilot episode aired on Fox, Eddie also states, "Because, in marriage, women stop fun from happening".
}

homes tuned in to watch the screwball antics of television's favorite expectant parents (McNeill, 1996: p. 402).

I Love Lucy provides a stunning example of the power television exerts in blending fact and fiction (McNeil, 1996), bridging public and private life (Landay, 1999), and, thus, incorporating as well as influencing social mores. ${ }^{3}$ In sitcoms, this is particularly true with regard to gender. It is no surprise, given comedy programming's roots in radio and Vaudeville, that a recurrent theme is the "war between the sexes". I Love Lucy is the first in a long line of television influences that have both mirrored and molded gender roles in general and the maternal in particular.

In one sense, I Love Lucy was progressive for its time. Born from the radio program My Favorite Husband in which Ball

\footnotetext{
${ }^{3}$ While detractors may claim that television does not influence behavior, the social experiments and Social Learning Theory of psychologist Albert Bandura offer compelling evidence that media such as television play at least a role in shaping our lives. Bandura's 1961 "Bobo doll" study, in which he showed children films of adults aggressively interacting with an inflatable plastic clown and then observed the children's subsequent unsupervised play with Bobo, demonstrated that the children effectively modeled the antisocial behavior and even extrapolated novel ways of attacking the doll. Because of these findings, Bandura testified before Congress about the links between television violence and aggressive behavior in children, although he was blackballed by television network officials "from taking part in the 1972 Surgeon General's Report on Violence" (Griffin, 2003: p 368; see also Bandura, 1977). We also contend that, were there no link between television viewing and behavior, advertising would not be a multibillion-dollar industry.
} 
had starred with Richard Denning, I Love Lucy showcased a female comedic lead, both in name and content (McNeill, 1996). Lucy Ricardo, as Lori Landay notes in "Millions 'Love Lucy", took on the role of the "trickster":

A subversive, paradoxical fantasy figure who does what we cannot or dare not by moving between social spaces, roles, and categories that the culture has deemed oppositional. When faced with a situation that appears to have only two choices, the trickster is the kind of hero/ine who creates a third possibility. (1999: p. 26)

Lucy, the 1950s housewife and mother who envies her husband's public life in the limelight, tries to transgress traditional gender boundaries in nearly every episode. (Of course, Lucy does not do this within the narrative as a conscious feminist protest, but rather, like a child, to be the center of attention and admired as talented and desirable.) However, what is funny is Lucy's glaring failure when she ventures beyond the bounds of domesticity. Regardless of its "proto-feminist" themes and Lucille Ball's own career success, in the end I Love Lucy reifies traditional gender roles and sends television women and mothers back to the home and kitchen (with consumer product doorprizes in exchange for real role revolution).

The "third possibility" in popular television is, apparently, not possible. In the same vein as I Love Lucy, other early sitcoms depict the woman/wife/mother as like a child to the man/husband/father (e.g., Granny in The Beverly Hillbillies or Aunt Bee in The Andy Griffith Show). Mothers are loved and lovable, even if their incompetence (think Lucy Ricardo) or Madonna-esque innocence (Edith Bunker in All in the Family) routinely creates problems for men.

Twenty years after Lucy gave birth to Little Ricky, and in the midst of a national debate over the ratification of the Equal Rights Amendment, film theorist Laura Mulvey called for the realization of Landay's "third possibility" for viewers: a new form of visual pleasure no longer slavishly dependent upon the masculine, but one that recognizes the feminine and maternal (Mulvey, 1992). ${ }^{4}$ As second wave feminists in the 1970 s directly questioned traditional gender boundaries, contemporary sitcoms incorporated such glass-ceiling struggles into storylines. Top-ranked sitcoms such as All in the Family, Laverne and Shirley, and Three's Company exemplified the burgeoning sexual awareness of the nation during prime time, that block of evening viewing the networks would deem (at the behest of Congress and the 1975 Federal Communications Commission) the "family hour". Even the mid-decade popularity of Happy Days, with its romanticized, regressive idolization of the 1950 s as a time when men and women knew their place (and presidents could be trusted), buoyed the reality of the transitioning times simply by protesting too much

Despite the efforts of Lucy/Lucille, Mulvey, and other forward-looking women, the sexual revolution at least in popular television comedies has been a pyrrhic victory. In this pilot project, we chart the depiction of women, wives, and mothers over a half-century of American sitcom history. Initial findings suggest that, while television sitcoms have altered the roles of women in an effort to keep up with changing social norms, they have failed to meaningfully alter traditional masculine narratives. Instead, what has been won is a superficial role reversal - unthreatening and, thus, ultimately allowed by capitalism-

${ }^{4}$ Written in 1973, Mulvey's influential article "Visual Pleasure and Narrative Cinema" was first published in 1975 in Screen, 16(3), 6-18. with sitcoms portraying men as children and women as mothers responsible for disciplining them. Like Lucy, whose tomfoolery predictably backfires and inevitably exposes her as the dupe (Landay, 1999), women, wives, and mothers in top-rated sitcoms such as The Cosby Show, Roseanne, Cheers, Home Improvement, Seinfeld, and Friends transform from lovable nuisances to not-so-lovable nags, or worse.

\section{Methodology}

Second and third wave feminism and an equal rights movement seem to have only relieved television women of their sense of humor and capacity for fun-a curious thematic development in situational comedies. In this sitcom evolution, woman becomes mother, mother becomes nag.

This finding has emerged from a pilot project examining situational comedies that earned the highest average seasonal A. C. Nielsen Company ratings from the proliferation of television in 1949 to the present (Nielsen Media Research, 2007; McNeil, 1996). A Grounded Theory methodology (Glaser \& Strauss, 1967; Glaser, 1978; Strauss \& Corbin, 1998) was used to analyze emergent themes from a pilot sample of top-rated sitcoms. Sitcoms, during this six-decade time span, have earned the highest Nielsen rating 25 times. Because some sitcoms earned the rank of being America's most-watched prime-time program more than once, of these 25 seasons there are 13 distinct shows (see Table 1). We focused our analysis on the episodes from the first season a sitcom garnered the highest Nielsens. When the first top-ranked season was unavailable, the available season closest to it was used. An analysis of all sitcoms or even sitcoms ranked in the yearly Nielsen "top 20" was beyond the scope of this pilot project, which aimed to identify dominant themes and patterns related to gender portrayal in the most-popular sitcoms throughout the history of television. An expansion of this pilot project involving a more-inclusive sample is currently being completed, with an article to follow. (This second article focuses on three tropes related to gender that have not changed over the course of television history, regardless of social reformations: woman as overly emotional, woman as intolerably talkative, and woman as inherently costly for men.)

Although researchers both in academia and advertising concede that Nielsen television viewer ratings "are not without measurement error" (Prior, 2009: p. 132), the A. C. Nielsen Company has enjoyed a virtual monopoly in the audience research industry since before the inception of television (Wood, 1962; Buzzard, 2002). Nielsen's company began monitoring the preferences and habits of television viewers in 1950, using so-called "Nielsen families" selected from a random, representative sample of all American households based on US Census Bureau data. Initially, this consisted of approximately 1200 homes, but sample size was increased in 1983 to roughly 1700 due to the proliferation of programs, the rise of cable, and the newly identified need for demographically based "narrowcasting" (Stoddard Jr., 1987). Industry competitors emerged in the mid-1980s and pressured the Nielsen Company to increase its sample size, which today numbers about 5000 households (Nielsen Media Research, n.d.).

Nielsen ratings originally were calculated via two methods: a patented Audimeter that attaches to a family's television and "record[s] automatically whether a set is on or off and to what channel it is tuned" 365 days a year (Buzzard, 2002: p. 274) 
Table 1.

Broadcast network situation comedies with the highest seasonal Nielsen ratings from 1949 to the present.

\begin{tabular}{|c|c|c|c|c|}
\hline Situation Comedy & Network & Broadcast Dates & ${ }^{\#} 1$ Rank in Nielsens ${ }^{a}$ & Season Analyzed $^{\mathrm{b}}$ \\
\hline I Love Lucy & CBS & 15 October 1951-24 June 1957 & $\begin{array}{l}1952-1953 \\
1953-1954 \\
1954-1955 \\
1956-1957\end{array}$ & $1952-1953$ \\
\hline The Beverly Hillbillies & CBS & 26 September 1962-7 September 1971 & $\begin{array}{l}1962-1963 \\
1963-1964\end{array}$ & $1962-1963$ \\
\hline The Andy Griffith Show & CBS & 3 October 1960-16 September 1968 & $1967-1968$ & $1964-1965$ \\
\hline All in the Family & CBS & 12 January 1971-21 September 1983 & $\begin{array}{l}1971-1972 \\
1972-1973 \\
1973-1974 \\
1974-1975 \\
1975-1976\end{array}$ & $1971-1972$ \\
\hline Happy Days & $\mathrm{ABC}$ & 15 January 1974-12 July 1984 & 1976-1977 & 1974 \\
\hline Laverne and Shirley & $\mathrm{ABC}$ & 27 January 1976-10 May 1983 & $1977-1978$ & 1976 \\
\hline Three's Company & $\mathrm{ABC}$ & $\begin{array}{l}15 \text { March 1977-21 April } 1977 \\
11 \text { August 1977-18 September } 1984\end{array}$ & $1978-1979$ & $1978-1979$ \\
\hline The Cosby Show & NBC & 20 September 1984-17 September 1992 & $\begin{array}{l}1985-1986 \\
1986-1987 \\
1987-1988 \\
1988-1989\end{array}$ & $1985-1986$ \\
\hline Roseanne & $\mathrm{ABC}$ & 18 October 1988-20 May 1997 & $1989-1990$ & $1989-1990$ \\
\hline Cheers & NBC & 30 September 1982-19 August 1993 & $1990-1991$ & 1988-1989 \\
\hline Home Improvement & $\mathrm{ABC}$ & 17 September 1991-25 May 1999 & 1993-1994 & 1993-1994 \\
\hline Seinfeld & NBC & $\begin{array}{c}\text { 31 July } 1989 \\
\text { 31 May 1990-21 June } 1990 \\
\text { 23 January 1991-26 June } 1991 \\
\text { 18 September 1991-14 May } 1998\end{array}$ & $\begin{array}{l}1994-1995 \\
1997-1998\end{array}$ & 1994-1995 \\
\hline Friends & $\mathrm{NBC}$ & 22 September 1994-6 May 2004 & 2001-2002 & 2001-2002 \\
\hline
\end{tabular}

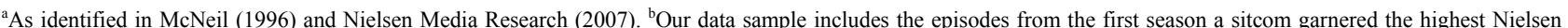
ratings. Four of these seasons, however, were unavailable and, thus, the available season closest to it was used: The Andy Griffith Show, 1964-1965; Happy Days, 1974 (midseason premiere); Laverne and Shirley, 1976 (midseason premiere); and Cheers, 1988-1989.

and paper diaries in which individual viewers log what they watch for one week during four to six "sweeps" months (Napoli, 2005). During the 1980s, Nielsen and its (now vanquished) competitors developed the "Peoplemeter" in order to combine and automate these two data collection tasks. Ironically, the Peoplemeter was not necessarily an improvement in methodology, both due to the costs and "the need for viewers to actively participate in the ratings process" (Buzzard, 2002: p. 289). What's more, Nielsen's dominance of the industry has proven unflappable and today "Nielsen is alone in measuring TV ratings despite attempts by four rivals to compete" (Buzzard, 2002: p. 289). Nielsen thus provides the only comprehensive ratings throughout the era of television and is used here for these reasons, even though changes in data collection techniques over the years and self-report diaries introduce methodological concerns.

Regardless, examining the nation's most-popular television programs offers insight into mainstream American culture. Networks use Nielsen ratings to determine what to broadcast and when (as well as how much commercial air time during programs will cost). In a reciprocal way, viewers and television ratings exert an influence on what popular culture exists from season to season. Alternative and avant-garde programming also have emerged and even flourished during the era of this medium, particularly with the rise of cable and the Internet. However, the consistent accessibility of broadcast prime-time offerings places them in a unique position in the American household to capture (and reflect) the attention of viewers and to influence the collective consciousness. ${ }^{5}$

\section{Viewing Pleasure and Gender Roles}

\section{The Traditional Woman}

In the early days of television, women were funny, wacky, foolish, senseless, self-centered, impatient, impulsive, needy, sweet, and mothering, or some combination thereof. Driven by emotions rather than reason, their opinions and desires (real or imagined) resulted in misadventure and, thus, entertaining plot twists. In turn, their male counterparts, to whom they generally deferred, often functioned as the "straight man", caring for the women and cleaning up their messes. Nearly every episode of $I$ Love Lucy centers on the silly schemes Lucy concocts that Ricky ultimately must solve, whether it be Lucy handcuffing herself to her husband ("The Handcuffs", Oct. 6, 1952, episode 37), fighting with best friend Ethel ("The Club Elections", Feb. 16, 1953, episode 47), wanting a bigger apartment ("The Ricardos Change Apartments", May 18, 1953, episode 61), or falling prey to less-than-reputable door-to-door salesmen ("Sales Resistance", Jan. 26, 1953, episode 45). ${ }^{6}$ A recurrent theme in I Love Lucy is Lucy's ineptitude. While the title to the Feb. 2, 1953, episode "The Inferiority Complex" suggests her lack of talent is all in her head, the content underscores Lucy's true uselessness in everything nondomestic. Ricky, Fred, Ethel, and even the psychiatrist Ricky hires collude in patronizing Lucy, pretending her poorly told jokes are funny, her unreliable 
bridge-playing skills are every partner's dream, and her caterwauling she considers singing is delightful. The psychiatrist even goes so far as to woo Lucy, saying she is a "living doll" and a "gorgeous creature", when in the end, Lucy is no more than a big baby, needing to be appeased and wailing in her signature fashion whenever she fails to get her way ("The Inferiority Complex", Feb. 2, 1953, episode 46). Women in other sitcoms of this era are depicted similarly and must be managed by their men. Granny and Aunt Pearl in The Beverly Hillbillies cook up plots as frequently as they do vittles, and Mrs. Drysdale and other minor characters in this same show use men for money. ${ }^{7}$ Even the voluptuous tomboy Elly May-an asexual sex object who refuses to be feminized or "citified"-must be coerced into wearing dresses and controlled when she climbs trees, "wrassles" her cousin Jethro, and like a child mothers any

${ }^{5}$ Of course, sitcoms that have not earned the highest Nielsen ratings still have been watched by millions of Americans (along with viewers abroad) and also influence the broader culture. Due to the limited space an academic journal allows, we have focused our methodology for this article only on the top-earning situational comedies. A more in-depth examination of 60 years of comedic television programming is better suited to a book of its own and is under way. Regardless, we contend that a majority of popular sitcoms beyond our sample still conform to our main thesis. Shows such as The Mary Tyler Moore Show, Married with Children, Murphy Brown, Scrubs, and 30 Rock have been cited by some critics as alternatives to the mainstream fare. Mary Tyler Moore's Mary Richards, however, is comparable to Laverne and Shirley's Shirley Feeney as a transitional female character: still funny but increasingly responsible and, thus, "maternal" in comparison to her zanier compatriots. Peggy Bundy, the spandex-wearing, self-centered, buxom spouse of Married with Children's ne'er-do-well salesman, Al Bundy, is anything but maternal. Sex-crazed and lazy, she is a far cry from the television housewives of the 1950s, '60s, and '70s (whom actress Katey Sagal parodies in her portrayal), and, for $\mathrm{Al}$, she is certainly a nag. Bundy daughter Kelly offers nothing new as the dumb, blonde sex object, leaving the only female character befitting feminist ideals to be boyish neighbor Marcy Rhoades/D'Arcy who dominates her husbands. Likewise, Candice Bergen's Murphy Brown commanded this late-1980s series as a grouchy, no-nonsense television reporter and anchor who delighted in torturing her young, male boss and was difficult to please, eventually forcing the weekly parade of her inept secretaries to form a support group. Two recent episodes of Scrubs and 30 Rock also are telling. In "My Nah Nah Nah", surgeon Christopher Turk informs a patient's father that he wants to try an experimental procedure but he must "clear it with his boss" first. Dr. Turk is next shown rushing past the hospital's chief of medicine and instead seeking permission from Carla, a nurse and his wife (Scrubs, "My Nah Nah Nah", March 18, 2009, episode 811). Like Carla, 30 Rock's Liz Lemon, played by creator Tina Fey, serves in a maternal role to her immature, irresponsible coworkers, including her boss. Her competence, however, is isolated to the workplace, and she repeatedly bears the brunt of jokes about her inferior looks and inability to "bag" a man. Even when Liz Lemon dates an attractive but incompetent and overindulged doctor in "The Bubble", 30 Rock's jokes center around the discrepancy in their looks but their common inadequacies in bed (March 19, 2009, episode 315). "Ethnic sitcoms" written by and/or featuring minority entertainers have not followed the trend we depict in this paper to the same degree. This may be due to the fact that they have had a tendency to "[take] up the mantle of traditional parenting that white sitcoms have shed. For years TV's white parents have been crass (Roseanne), dumb (The Simpsons), even abusive (Titus). On My Wife [and Kids] and Bernie Mac, black dads don Ward Cleaver's authority-figure sweater" (Poniewozik, 2002: p. 64; see also Frazer \& Frazer, 1993). Still, Poniewozik cites Damon Wayans' depiction of his fatherly character on My Wife and Kids as "a bit of a Neanderthal", and Susan Horsburgh and Ulrica Wihlborg describe Kellita Smith of The Bernie Mac Show as "rul[ing] the TV roost as Bernie Mac's wife" (2002: p. 105).

${ }^{6}$ In the postwar world of television, the "solutions" to Lucy's conundrums typically involve the purchase of consumer products. See Landay's (1999) "Millions 'Love Lucy" for further discussion about how television helps create perpetual, product-based desire as demanded by capitalism. It is also interesting to note that, in both our pilot and our expanded samples of sitcoms from the 60 years they have been broadcast into American homes, one theme that has not changed is the idea that women cost men money. No matter how liberated women become, male sitcom characters routinely complain about the "costs" of interacting with women. critter, domesticated or otherwise, she can find.

Reliable bank assistant Jane Hathaway may be the exception, but the writers make clear in "Granny's Spring Tonic" that she has, unlike Elly May, consciously jettisoned her feminine desires to be a wife and a mother. In this episode, Jane Hathaway compliments new employee Gloria Buckles, who like Hathaway is a "modern" but mousy woman, for her dedication to her job: "[A]lready she has displayed those qualities so rare in a modern girl: eagerness to learn, willingness to work, loyalty to the bank, devotion to duty... Unlike so many others, this girl is not here to find a husband. She is here to work. Right, Gloria?" (March 27, 1963, episode 27). While the humor in this episode stems from the fact that Gloria Buckles, who transforms from plain-Jane to pin-up with a change of clothes, is nothing but a nefarious gold-digger after Jed's millions $(\$ 34,783,127.34$, as she recites repeatedly in her head), Ms. Hathaway, with her masculine, prim demeanor, is left holding the bag: forced to simultaneously forsake her femininity but still predominantly serve the needs of men, be it greedy boss Mr. Drysdale or wise client Jed Clampett and his family. Her character foreshadows the changes to come in sitcom women - the archetype of a woman who is liberated yet still limited in the roles she may play in a male-dominated society.

Similar to Lucy and Granny, matronly Aunt Bee in The Andy Griffith Show is anything but liberated and, though she may offer more stability and sage advice than either of her predecessors, she too frequently must be placated by her younger, male complement, Sheriff Andy Taylor. When Aunt Bee gets a part in the town pageant, for example, Andy and his son, Opie, make Bee feel guilty about leaving her "boys" alone. (As Opie purposely states, "I'll be glad when that pageant's over. I'm getting tired of eating at the diner".) They do this not necessarily for selfish reasons but because Bee, like Lucy, is terrible in the play and the director has found someone better. Rather than telling her and risk hurting her feelings, she is conned into choosing motherhood over her own ambitions ("The Pageant", Nov. 30, 1964, episode 138). Archie Bunker in All in the Family, on the other hand, does not mince words about his wife, Edith, whom he calls "Dingbat" and constantly orders to "stifle" herself. Although as the "fool" she technically depicts the calm next to Archie Bunker's blusterous storm, like Aunt Bee she is an older, asexual matron without a fully formed identity. Nowhere is this more apparent or more telling than in a 1972 episode called "Edith's Problem", focusing on Edith going through "the change". When Edith's husband and daughter Gloria seek medical attention for Edith's menopause, the "groinocologist" tells them to treat her with kid gloves and refrain from upsetting her (now a "Super-Dingbat", according to Archie, until the prescribed hormone supplements take effect). It is also up to the daughter, a liberated woman, to educate the mother about her body and herself. "Imagine, you having to tell me what's wrong", Edith laments. "When I was a young girl I didn't know what every young girl should know. Now I'm gonna be an old lady and I don't know what every old lady should know" ("Edith's Problem", Jan. 8, 1972, episode 214, emphasis original). ${ }^{8}$

\footnotetext{
${ }^{7}$ For example, Granny and Pearl repeatedly try to marry off Granny's granddaughter, Elly May, and Pearl's daughter, Jethrene (played by Max Baer Jr. in drag). Pearl also tries to bag oilman Mr. Brewster for herself. Mrs. Drysdale, moreover, is a hypochondriac who spends much of her time visiting various doctors in Boston, and Mr. Drysdale also must pay for her son, Sonny, to attend an Ivy League college back East.
} 
Despite the burdens these early sitcom women engender for their men, their mature male counterparts cherish them nonetheless. As Mr. Drysdale says of his wife, Mildred, "She's a snob, she's a hypochondriac, she's not young and beautiful, but I love her". Granny, on the other hand, pities the banker, declaring to Jed: "Poor man. He's got all of the trouble and none of the fun" ("The Clampetts Meet Mrs. Drysdale", Oct. 17, 1962, episode 4). In this way, the early American sitcoms lend support to a patriarchal hierarchy, where women (like children) represent a chaotic force that must be tamed, so that by show's end, the women are schooled from lessons learned and are ultimately dutiful, at least until the following week.

It is not unexpected that these early sitcoms represent women in this fashion. As feminist Betty Friedan chronicles in her 1963 book, The Feminine Mystique, the notion of "The Happy Housewife Heroine" began appearing repeatedly in the pages of women's magazines in 1949. What is surprising, however, is that this "traditional" view of women/wives/mothers as but accessories to their men and concerned solely with the domestic and familial spheres was new or at least re-imagined. In the 1930s and 1940s, as Friedan explains, the "majority of heroines in the four major women's magazines... were career womenhappily, proudly, adventurously, attractively career women" (1997: p. 85). This shifted in the 1950s: "By the end of 1949, only one out of three heroines in the women's magazines was a career woman - and she was shown in the act of renouncing her career and discovering that what she really wanted was to be a housewife" (1997: p. 93). Friedan notes that male (and even female) magazine editors and writers determined that American women of the 1950s and 1960s "were not interested in politics, life outside the United States, national issues, art, science", or even abstract ideas (1997: p. 100), thus refashioning the image of women in popular culture-no longer spirited and independent but "housewife-mothers, who cherish their 'differentness,' their 'unique femininity,' the 'receptivity and passivity implicit in their sexual nature"' (1997: p. 110). This essentialist depiction evident in magazines is repeated in early American sitcoms, despite the fact that one in three women at the time worked outside of the home (Freidan 1997).

\section{The Liberated Woman}

In the 1970s, TV's top-rated sitcoms candidly confronted the question of gender by creating characters that challenged earlier maternal roles and sought a new visual pleasure for viewers-a pleasure in step with the rise of second wave feminism, the sexual revolution, and the federal adoption of the Equal Rights Amendment. These sitcoms ushered in a succession of single women (sometimes contrasted with the previous generation's matriarchs), whose roles are less well defined, question classical notions of maternity, and increasingly drive narrative action.

Shirley's relationship with her mother in the sitcom Laverne and Shirley embodies this second wave transition. When Lily Feeney criticizes the company her daughter keeps ("You're still with shore patrol and bowlers and sewer workers and 'Iggly' and 'Squiggly' from upstairs"), Shirley tells her mother, "Well,

\footnotetext{
${ }^{8}$ Edith's character as the "Dingbat" was, of course, intentionally ironic on the part of the creators, and her lines often work double time as both funny and wise. The same could perhaps also be said of Lucy Ricardo, Granny Moses, or Marion Cunningham from Happy Days. With their traditional, subservient roles in the household, however, each of these characters fails to carve out a new possibility for television women significantly different from the conventional housewife narrative.
}

I think I'm old enough to pick my own friends". And Laverne comes to Shirley's defense after Lily questions her daughter's choices and sexual reputation: Lily pleads, "Why can't I go back [to California] and say, 'Oh, Shirley, Shirley has found a wonderful man and they have a lovely house in the suburbs and her life is going up, up'? ... Well, Shirl, what's it going to be? Is it going to be the good life or bimbo city?" Laverne promises Lily that she does not "have to worry about her [Shirley] be coming no bimbo, 'cause I'm watching out for that". Interestingly, Lily's first response is to ask, "Am I really a nag?"dialogue that simultaneously conveys that grown women need no longer be treated like children and, unfortunately, that women, particularly mothers, are to blame for this older, patriarchal ideal that a woman's place is in the home. If the connotation here is too subtle, Shirley ends the conversation by telling her mother, "I know you love me. The trouble is, you don't like me". Moreover, Lily is depicted as a failed role model of the traditional ways: She is a divorcée who married "one of those guys" and "end[ed] up trying to eat [her] way to happiness" ("Mother Knows Worst", May 18, 1976, episode 15).

In contrast, Shirley is employed, self-supporting, independent-minded, and attractive, though not necessarily a sex object. Importantly, she is still funny. The same can be said of Laverne, Janet from Three's Company, and Gloria from All in the Family. These characters take on roles traditionally deemed masculine: Laverne and Shirley work in a brewery and endure the juvenile antics of neighbors Lenny and Squiggy; "Good Old Reliable Janet" heads a household that includes an innocent bimbo and a not-so-innocent bumbler (Sept. 19, 1978, episode 301 ); and Gloria, although she lives with her parents (who illustrate the old days), works while her husband attends college. These women also are more in tune with their bodies and themselves, actively pursuing personal interests and sexual pleasure. In "Mike's Problem", for example, Gloria grows anxious when her husband experiences stress-induced impotence (Nov. 20, 1971, episode 208), and in "The Love Diary", Janet, who is juggling four suitors at once, has no desire to be "tied down" by marriage (Sept. 26, 1978, episode 304). Even in Laverne and Shirley, a sitcom set in the 1950s, the title characters straddle the line between classic gender roles and those of the liberated woman. In "The Society Party", Laverne tells Shirley that a high society gentleman would only want Shirley for "one reason - to have a good time, a few laughs, and a little vo-de-o-do-do". Although Shirley stops short of questioning society's sexual double standard (as a feminist in the mid-1970s might do), she vocally stands up for herself: "I don't vo-deo-do-do". "You vo-de-o-do-do", Laverne retorts knowingly and with a smile. "I don't vo-de-o-do-do", Shirley emphasizes, as a traditional woman would. "You vo-de-o", Laverne responds, and Shirley, the precursor of a modern woman, concedes: "Once. I was going steady for a whole year" (Jan. 27, 1976, episode 1, emphasis original).

Simultaneously, these characters reject other feminine stereotypes. Laverne cannot cook and neither can Janet or roommate Chrissy Snow, and unlike Lucy Ricardo, Shirley Feeney was written out of Laverne and Shirley after a pregnant Cindy Williams "chafed at working fourteen-hour days and demanded that her hours be specified in writing" (McNeil, 1996: p. 470). Unfortunately, a traditional "solution" to the pregnant employee "problem" was instituted and marriage to medic Walter Meaney was the vehicle used for Shirley's demise (McNeil, 1996).

Meanwhile, although Happy Days offered nostalgia in content and form about a time when masculine narratives pre- 
sented young men pursuing young women (whose own narratives remained untold), sitcoms in the 1970s introduced a version of the modern man. In All in the Family, Gloria's husband, Michael Stivic, stands in sharp contrast to his sexist, racist, homophobic, bull-headed father-in-law. Unlike Archie, Mike openly questions capitalism and the workings of government, he knows more about menopause than his mother-in-law, and he is taken to task by his wife for his sexual wanderings prior to marriage. When one of Michael's ex-girlfriends abandons her child on the Bunkers' doorstep, Edith, in a traditional role, maintains, "You can't blame him for having a good appetite". Liberated Gloria, however, grills him until "5:30 in the morning... [saying] everything there is to say. Twice" ("Mike's Mysterious Son", Jan. 22, 1972, episode 218). Archie's nickname for the man who married his daughter is "Meathead", hinting at a traditional disapproval of this new, modern man, just as Shirley's mother cringed at the burgeoning modern woman. Three's Company similarly introduces Jack Tripper, who, in order to live among liberated women, pretends to be gay.

As the authority of women in television comedies ascends, then, traditional masculinity is rendered impotent. Yet, this role reversal provides neither equality nor an unambiguous selfimage for women. While the traditional maternal role wanes, woman's identity blurs. Three's Company reveals this dilemma that will be perpetuated in sitcoms to come: Chrissy, a buxom dumb blonde, is "everywhere... a girl", while Janet, a "very bright" modern woman, half-jokingly compares herself to a "gorilla" and a "chimp" ("Pilot "2", unaired). Like Lily Feeney, Janet's self-incriminations lay the blame for demonizing women at feminism's feet. Simultaneously, Jack, for even appearing to be the modern "good guy" who does not objectify women, must suffer questions about his sexuality. In reality, however, Jack's desire to find a mature, monogamous relationship is merely a façade he knowingly uses - in conjunction with other outlandish lies - to pursue women. In "Double Date", Janet acknowledges she is wise to Jack's true character. "But you are a creep", Janet says, to which Jack responds, "I know, but I just didn't want you to think it" (Sept. 12, 1978, episode 302, emphasis original). Jack and Janet, both masculine characters, repeatedly impugn feminism in Three's Company. In "Jack Moves Out", Jack replies to Janet's complaint about how he leaves the toilet seat up with, "Well, excuuuuuse moi. I suppose you want me to apologize now for being a man" (May 8, 1979, episode 319, emphasis original), and Janet, in "Triangle Troubles", reduces the liberation of women to sexual exploitation, telling Jack, "The last time you went out with an oldfashioned girl we had to stay at the Regal Beagle [a neighborhood bar] 'til you modernized her" (May 15, 1979, episode 321). In this way, Three's Company seems to ask, rather than tell the viewer, what will the modern woman be?

\section{The Modern Woman}

Not until the 1980s would America's most-watched sitcoms present clearly defined roles for the modern woman and mother. In both The Cosby Show and Roseanne, viewers are treated to married couples in which husband and wife occupy seemingly equal positions. Cliff and Clair Huxtable work as physician and lawyer, Roseanne and Dan Connor hold blue-collar jobs. In each case, both adults share the parental burden (a far cry from Lucy and Ricky) and, at first glance, intellectual common ground. Roseanne goes a step further, offering a new type of mother. For the first time, a top-rated sitcom depicts a woman whose appeal is rooted primarily in her comedic ability to drive the narrative. Although the same could be said of Lucille Ball, Roseanne Barr's physique is perhaps more illustrative of the "everyday woman" than Ball's more glamorous pin-up figure forged in Hollywood.

Unfortunately, neither The Cosby Show nor Roseanne produces a radically new perspective on the feminine and maternal. Both sitcoms overstate the dominance of their leading women, thus completing the role reversal that began in the 1970 s by turning the woman/wife/mother into a seemingly classic "straight man" in opposition to the now more fun-loving man/ husband/father. In the part of "straight woman", Clair's primary activity in The Cosby Show is to discipline her endearing husband (like she does her children), through knowing disapproval, denying permission, scolding, or nagging. For example, iresponsible about his diet, Cliff must sneak into the kitchen and clandestinely obtain his favorite foods lest he be reprimanded by his wife, and in the episode "Off to the Races", the 50year-old physician seeks Clair's permission to compete in a charity relay race (May 8, 1986, episode 225). Bill Cosby's character, Cliff, dominates the comedic space of the household in his playful interactions with children and friends, while Clair looms as the distant authoritarian.

Roseanne's character also conforms to the straight woman motif, though not as straightforwardly as Clair. While Roseanne Barr's sarcastic humor is relentless, her position as a "funkiller" (for both her husband and her children) is repeatedly revealed week to week. This is taken to the extreme in the episode "Sweet Dreams", where an exhausted Roseanne, who feels like a "warden... responsible for everybody", merely wants "ten minutes alone in [her] own bathroom", "a sink with a stopper that actually works", and a bathtub that doesn't leak. Unable to fulfill these desires, she falls asleep and dreams about killing her self-centered children and bothersome husband. When the judge sentences her to 25 years to life, Roseanne replies, "I got 25 years to life when I married him". However, like the straight man, she quickly states for the record that this “wasn't a wise crack. I wanted 25 years to life. That's why I married him. I love him" (Nov. 7, 1989, episode 305). As illustrated here, Roseanne portrays the modern woman's dilemma: The true love she feels for a man is dangerous (in a tiresome, "fun-killing" sense) to men and children. In this way, the straight woman is "straighter" than the classic straight man.

Whereas classic straight men Ricky, Jed, Andy, and Howard (from Happy Days) are likeable authoritarians (and admired as a musician, millionaire, sheriff, and hardware store owner, respectively), the modern woman comes across, at best, as an annoyance and, at worst, as a Harpy. Because of this, the modern woman's femininity and maternal fitness are put on trial. In "Sweet Dreams", Roseanne's own friend, Crystal, takes the stand against her:

Your honor, Roseanne had the best husband in the world and what she did is unforgiveable... Let's cut the crap here, your honor. We all know Roseanne. We all know what she's like. She's loud and she's bossy and she talks with her mouth full. She curses at people when she drives. She feeds her children frozen fish sticks and high-calorie sodas. And she doesn't have proper grooming habits. And most important, your honor, she's married to the greatest 
man a woman could ever want and she don't appreciate him a lick. Dan Connor is tender and kind and loving and loyal and strong and masculine and sexy and virile... Your honor, I say hang the bitch. ("Sweet Dreams", Nov. 7, 1989, episode 305)

According to Crystal, Roseanne fails as woman, wife, and mother. In what is now an all-too-familiar anti-feminist "catfight" trope (Douglas, 1995), Roseanne in turn judges Crystal's success as a woman, defined by her ability to keep a man: "You had three men in your life and you lost them all. And I have been telling you... the only way you can keep a man happy is to treat him like dirt once in a while. Men do not like waify little cream puffs" ("Sweet Dreams", Nov. 7, 1989, episode 305). Roseanne's dream all but prescribes the role of modern women in future sitcoms as nagging, domineering, or demonized fun-killers, and this shift corresponds to a transformation in the roles of men, husbands, and fathers, who-if they refuse to be emasculated by their women-become childish pleasureseekers around which the sitcom's narrative develops. In these new roles, the greatest threat to a man's happiness is his wife. ${ }^{9}$

The quintessential example of these new roles is the 1990s sitcom Home Improvement, in which stay-at-home wife and mother Jill Taylor must bear the impulsive, reckless, perilous antics of not only her three male children but also her husband, talk-show host Tim, who lives primarily for hotrods and power tools but - similar to Lucy Ricardo-masters them only in his fantasies. And unlike Ricky from I Love Lucy, Jill's reprimands border on vitriolic, as when she tells Tim to "do us all a favor and shut up" or "I don't dream about you, Tim. It's bad enough I have to see you when I'm awake" ("Dream On", Jan. 12, 1994, episode A362).

Sitcoms, post-second wave feminism and in the midst of an ill-defined third wave feminism, render the modern man a simplistic boob. In fact, Three's Company unashamedly brands Jack with this designation. After Jack moves out of the apartment he shares with Janet and Chrissy, Janet builds a booby trap (which, ironically, consists of several pots and pans strung together that neither woman ever uses for cooking) underneath one of the windows that does not lock. When Jack later decides to return home and climbs through the window because he has forgotten his key, he trips the trap and causes a commotion. Chrissy's dialogue needs no interpretation: "Janet! I think your trap caught a booby!" (“Jack Moves Out”, May 8, 1979, episode 319). ${ }^{10}$ Like Jack, Sam Malone from Cheers, Kramer from Seinfeld, and Joey Tribbiani from Friends are but unmarried versions of Tim, with Sam's predatory libido, Kramer's playful mischievousness, and Joey's charming stupidity unchecked by the modern woman. Viewers root for these male characters to win, unlike their emasculated equivalents: gender-enlightened

${ }^{9}$ It is not only in Roseanne's dreams that this role reversal takes place. In "Somebody Stole My Gal", Roseanne half-jokingly warns Dan that he can't have any cookies "before you've had your dinner", and she forgives him for failing to fulfill a promise by telling him, "Honey, I'm your wife. I already hate you" (Oct. 3, 1989, episode 304). In "Guilt by Disassociation", moreover, she in not so many words calls her husband fat: As Roseanne readies herself for a job interview, Dan asks, "What do you know about packing meat?" Roseanne replies, "Well, I've been living with rump roast for 15 years". She also berates a confused Dan for not knowing where she is going:

ROSEANNE: Now, didn't we lay in bed for two hours last night talking about how important this was and now you're saying, "Where're you going?"

DAN: [humorously hanging his head and placing it on Roseanne's shoulder] Forgive me. I'm the worst husband who ever lived.

("Guilt by Disassociation", Sept. 26, 1989, episode 302)
Al Borland, whom Tim regularly and disdainfully compares to a wife and mother (see also McEachern, 1999); Cheers patron and psychiatrist Frasier Crane, who buckles under the thumbs of know-it-all dilettante Diane Chambers and frigid shrink Lilith Stern; Seinfeld-sidekick George Costanza, who escapes the unpleasant confines of marriage only after his fiancée (at one time a lesbian) dies; and "friend" (and serial divorcé) Ross Geller, who finds himself cuckolded by another woman.

Women, wives, and mothers, whether merely nagging or truly monstrous, threaten to end the modern man's happiness, tying him down and freezing the pleasure-driven sitcom narrative.

All hope, however, is not lost for the modern woman, though it is at best tenuous. There is acknowledgement, whether overt or subtle, in the more recent top-rated sitcoms regarding the way both pop culture and society have portrayed women, and there have been some attempts to change traditional ideals. In a season eight episode of Roseanne, for instance, Roseanne and her sister, Jackie, lament while on a road trip how the music of their generation was largely "guy music" such as "Take a Letter, Maria" (a secretary whom Roseanne says is "getting screwed twice") and "Baby, Baby, Don't Get Hooked on Me", about a man who tells his female counterpart "don't get hooked on me/'Cause I'll just use you, then I'll set you free". Like the modern woman she is, Roseanne's response to such a lothario is: "Use me, I'll set you on fire, you bastard". Even Jackie's attempt to think of "all those sweet guys, you know, like Donovan and, and Jim Croce and The Beatles" ends with a discussion of the main lyric in John Lennon's "Run for Your Life": "I'd rather see you dead, little girl, than to be with another man". Roseanne and Jackie, of course, immediately consider female greats such as Janis Joplin, Pat Benatar, Chrissie Hynde, and Patti Smith and then move on to toying with an "idiot trucker with the naked woman mud flaps" ("The Getaway, Almost", Nov. 14, 1995, episode 807). Unfortunately, this outright feminist discourse occurs in Roseanne's penultimate season, when it slipped to $16^{\text {th }}$ in national ratings compared to ninth, fourth, and second in the three years prior (McNeil, 1996; Nielsen Media Research, 2007).

Seinfeld also attempts to address feminist issues as part of the show's commentary on the always inconvenient and often illogical rules of society. For example, in an episode in which Jerry dates a Romanian gymnast who earned a silver medal inthe 1984 Olympics, Kramer convinces Jerry to pursue a more intimate relationship with the woman, believing the gymnast's flexibility will result in unimaginable sexual pleasure. When the reality fails to match this male myth, Jerry is saddled with dating the woman longer than he had planned (a torturous task limited to conversations about the horrors of Ceauşescu's dic-

\footnotetext{
${ }^{10}$ Paradoxically, labeling modern men as "boobs" not only fails to challenge the masculine narrative but also manages to usurp some of the feminine and maternal from women. Jack Tripper, immature and girl-crazy though he may be, is a culinary student with dreams of becoming a professional chef. By taking responsibility for all of the cooking, Jack maintains a respected position in the business world and in the household, simultaneously underscoring Janet's masculinity and undermining her femininity. (Chrissy's blatant ineptitude in the kitchen fails to stand out in light of her-as a sex object who yearns for a traditional relationship - implied receptive aptitude in the bedroom.) Capable in the realm of men but not in that of women, Janet's nondomestic independence borders on the mannish and hints at the monstrous femininity characters such as Roseanne, Carla from Cheers, and Elaine from Seinfeld will exhibit. Boob or no, male sitcom characters continue to work outside of the household, maintaining at least some of the power that defines traditional masculinity. What does change is their accountability.
} 
tatorship) in order not to be cast as one of those men Roseanne and modern women like her would set ablaze. Jerry eventually discovers, however, that the gymnast was only dating him because of fables in her country about the sexual prowess of comedians, and she ends the relationship when Jerry comes up short ("The Gymnast", Nov. 3, 1994, episode 606). Although this plotline and others in Seinfeld endeavor to even society's sexual score, the sitcom remains a story told from a male view: In "The Gymnast", Jerry tries to explain to Kramer that there is always a price to pay for sexual dalliances-whether an estimated three weeks of dating for one night of sex in order not to be labeled the "bad guy" or embarrassment in being exposed as a less than sexually satisfying man. Even Elaine, the one main female character in the sitcom, is treated as "one of the guys", and when her femininity is recognized, it is as something inherently different. Nowhere is this more obvious than in "The Contest" (Nov. 18, 1992, episode 411), in which Jerry, George, and Kramer make a $\$ 100$ bet to see who can forswear masturbating the longest. When Elaine wants in, the men refuse, explaining "[i]t's apples and oranges" and "[i]t's easier for a woman not to do it than a man". They only way the men concede is if Elaine gives them odds, with George demanding a two-to-one \$200 bet and Kramer upping it to \$1000. Just like the gymnast, a modernized Elaine loses the bet after succumbing to primitive sexual desire-working out behind a spandex-clad John F. Kennedy Jr. in her aerobics class-suggesting that men and women are essentially the same. This equality in terms of (sexual) pleasure, however, has its consequences. When John F. Kennedy Jr. finds out about the bet from Jerry's girlfriend, Marla, both Elaine and Jerry pay a price for engaging in such childish (and stereotypically male) antics: John F. Kennedy Jr. forgoes his date with Elaine to console Marla, who loses her virginity to him instead of Jerry. (George, the least "manly" character of the sitcom, is punished from the top of the show after his overbearing mother catches him in the act and ends up in the hospital because of it.) Failure to conform to more traditional gender roles quashes everyone's pleasure, other than the virtuous (i.e., virginal) Marla, the quintessentially masculine John F. Kennedy Jr., and Kramer, the "wild", Tim-like character in Seinfeld who makes no apologies for his self-satisfaction. This motif is repeated in other episodes, including "The Couch", in which Elaine's stance in favor of abortion rights ruins not only an evening at a popular restaurant but also Jerry's couch and Elaine's own relationship with a very attractive delivery man (Oct. 29, 1994, episode 605).

Women seem to fare the best as part of an ensemble cast such as Friends, where stories are told from the perspectives of all six of the main characters. Moreover, the women, while still predominantly in charge, are allowed to have fun. Two story arcs from the season Friends earned the highest Nielsen ratings focus on the women (although, again, in the more traditional, domestic spheres): Monica's marriage to Chandler and Rachel's unplanned pregnancy with Ross. Friends offers perhaps the most agreeable depictions of modern marriage and parenthood of this sample of sitcoms: Chandler honestly tries to decline having a bachelor party or patronizing a strip club with his boss; newlywed Monica happily buys her husband porn for Valentine's Day; Ross looks forward to being a hands-on father to his second child out of wedlock; and Rachel could not be more of an idealized pregnant woman - thin, fashionable, and desirable for most of the season regardless of her growing belly. Although more nuanced (and at times more outlandish) in terms of gender roles than earlier sitcoms, Friends still falls prey to common sitcom themes. Joey, an actor man-child who cannot manage much of his own life, beds the most women, while Chandler and Ross often are emasculated (by Monica and Rachel, among others) despite successful, respectable careers. (Because of Monica, for example, Chandler knows the names of several varieties of ribbon. As he offers Phoebe "lace, satin, sateen, raffia, gingham, [or] felt" to decorate a present, Chandler adds, "and I think my testicles may be in here, too" ["The One in Massapequa", March 28, 2002, episode 818].) A female version of Joey may be found in Phoebe, an adventurous, freespirited masseuse who is more sexually aggressive than the other women. In "The One Where Rachel Has the Baby: Part 1" (May 16, 2002, episode 823), for instance, Phoebe meets a man in the hospital where Rachel is about to give birth. Wanting to find out more before she makes a move, Phoebe asks Joey to question him. When Joey reports to Phoebe that the man is "not into anything weird sexually", Phoebe replies, "Enter Pheebs". (Unlike Joey, however, Phoebe, having grown up on the streets, can take care of herself.) Rachel at times resembles Phoebe (carefree and sexually forward, as when she hits on Ross prior to the pregnancy or is overly lustful in her fourth month due to the hormones) but at times is more like Monica (neurotic and needing to be in control, such as harping at Ross for his infidelity when they "were on a break" or irritably bossing him around in the last days of her pregnancy ["The One Where Rachel Is Late", May 9, 2002, episode 822]). Ironically, although Rachel's pregnancy as a single woman is depicted as rather idyllic, Ross emerges as the most capable parent in the room (at Rachel's traditional, all-female baby shower). As Rachel frets about whether she will make a good mother and Rachel's mother offers live-in help for the first two months, Ross convinces both women that no assistance is needed: "Look, um, you know what, even if she [Rachel] doesn't know anything, I do. And I'll be there to show her... The point is, when the baby comes, I will be there to, to feed her [the baby] and bathe her and change her. And more than that, I want to do all those things" ("The One with the Baby Shower", April 25, 2002, episode 820).

Interestingly in Friends, mothers are not very maternal. Even though Rachel's mom (Marlo Thomas from That Girl) wants to help with the new baby, she admits that she relied on nannies, housekeepers, and alimony when her children were young, and Chandler's mom (played by Morgan Fairchild) spends most of Monica and Chandler's wedding having sex with her date in one of the hotel bathroom stalls. Throughout the sitcom, moreover, Monica's relationship with her mother is marked by the latter's unceasing critical disapproval, despite the fact that Monica is a successful chef, friend, sister, and wife. Like Seinfeld, Friends tries to paint a more modern picture of the sexes while poking fun at them simultaneously, but its jokes are bittersweet. For instance, after the gang regretfully watches a video of an actual birth, Monica exclaims, "Oh, my God! No wonder my mother hates me!" ("The One with the Birthing Video", Feb. 7, 2002, episode 815)

\section{Role Reversal}

There are certainly several ways to interpret this data, and an optimist might argue that shifting mothers from the clownish housewife in I Love Lucy to the earnest disciplinarian in Home Improvement represents at least a change and perhaps an im- 
provement. We contend that this role reversal demonstrates only a superficial transformation in the communal notions of femininity and motherhood and, ironically, maintains the longstanding form of masculine visual pleasure first identified in Laura Mulvey's 1975 paper, "Visual Pleasure and Narrative Cinema". Mulvey famously argued that visual pleasure in popular film involves a masculine narrative and that, to date, this appears to be the only narrative available to cinema-goers, even if they are women. ${ }^{11}$ Because the narrative is fundamentally masculine and ultimately concerned with man's work, his adventure, and his consumption of objects, women on-screen represent either a distraction from or a threat to the masculine narrative. To alleviate this "anti-male" threat, which Mulvey links to Freudian castration anxiety, the woman must be disarmed and either reduced to an object - which has no narrative of its own - or absorbed into the masculine narrative. Consequently, the masculine narrative presents women with only two possible roles: that of "The Perfect Product", the traditional role of sex object existing on-screen for the sake of the audience's (masculine) visual pleasure, or "The Bearer of Guilt", the obstacle thwarting masculine pleasure that must justifiably be punished, rescued, or subdued. In the role of "anti-male", the woman symbolizes castration and reminds viewers that while she may be the bearer of children, the bearer of culture, and the bearer of meaning in a narrative, she is not the maker of anything.

As the traditional sex object, the woman's visual presence on-screen "tends to work against the development of a story line, to freeze the flow of action in moments of erotic contemplation" (Mulvey, 1992: p. 750). "In herself the woman has not the slightest importance" (Budd Boetticher quoted in Mulvey, 1992: p. 750). Instead, she is, as Mulvey describes her, the "perfect product" for man's consumption, like the "Tool Time" girl in Home Improvement who plays a part no more substantive than boxing's bikini-clad ring card girls. In this role the woman is outside of the narrative; for narrative cohesion, then, the perfect product may be brought into the story as a fetish that inspires desire, love, fear, etc., and hence action in the onscreen hero. While characters such as Chrissy Snow and Elly May enjoy larger roles than the "Tool Time" girl, it is only for the sake of the masculine gaze and does not change these women's function as the male's sex-object-to-be-looked-at. In The Beverly Hillbillies, for example, Mrs. Drysdale's Ivy League son, Sonny, courts Elly May, openly telling her he is going to mold the perfect woman, worthy of the perfect man (himself):

SONNY: Oh you woodland spirit. You forest little bird. You are so refreshing after all those intellectual types at Vassar and Wellesley. You make me feel superior.

ELLY MAY: Is that good?

\footnotetext{
${ }^{11}$ This visual pleasure that Mulvey identifies in film with regard to looking or gazing also is similar in other media, including art and television (Pollock, 1992a, 1992b). In fact, the effect may be more pronounced in television, as TV is a more intimate medium that more closely mimics reality: "The more interesting television characters grow and change over time, creating layers of depth in their metamorphoses. We may even come to know these characters better than our own co-workers". Moreover, the "use of the story arc in television series helps to create a sense of realism... Story arcs help create an illusion that the characters have existed before and continue living between and after episodes" (Porter, Larson, Harthcock, \& Nellis, 2002: pp. 23-24). It also may be argued that television shows such as sitcoms linger in the popular culture longer as many are repeatedly broadcast via syndication.
}

SONNY: Good? It's divine. ("Elly's First Date", Nov. 21, 1962, episode 9)

Of course, as sex-object-to-be-looked-at, Elly May's romance ends immediately so that the primary masculine narrative - the Clampett family's enjoyment of capitalist consumption in Beverly Hills - may continue.

On the other hand, allowing the woman to be a part the narrative does not bode well for her, either. When not the traditional sex object, woman must be the "bearer of guilt", whether as a loveable Lucy who needs to be rescued and controlled or a not-so-loveable Jill Taylor who, like Lisa in Alfred Hitchcock's Rear Window, is "a drag" (Mulvey, 1992: p. 755). This is exactly what George Costanza discovers in Seinfeld after he intentionally hires a secretary who will not distract him sexually. Despite her mousy looks, George ends up having sex with her - in part because of her great organizational skills - and in the process promises her a raise. He complains to his boss, however, when he learns that she now makes more than him: "But, Mr. Steinbrenner, how can I be expected to perform my job properly knowing that my subordinate is making more than I am? With all due respect, sir, it's out of whack" ("The Secretary", Dec. 8, 1994, episode 609). There is little difference, then, between Ms. Hathaway from The Beverly Hillbillies and George's secretary, who are allowed to transgress conventional gender roles only at the expense of their fun and/or their femininity.

After second and during third wave feminism, television women acquire enough power beyond the private sphere and no longer require punishment, rescue, or submission. The "bearer of guilt" or "anti-male" woman, then, as Mulvey has described her, accrues characteristics that are also "anti-female", thus transforming her into something "unnatural". As a stand-up comedienne, for example, actress Roseanne Barr became infamous for grabbing her crotch while singing the national anthem. Failing to meet the culture's overblown qualifications for sex object, she is forced to act like a man in order to participate in the masculine narrative. But acting like a man produces individual and cultural consequences for women. Rejecting traditional marriage roles may result in divorce or spinsterhood (or even institutionalization!) ${ }^{12}$ delayed childbearing may lead to infertility ${ }^{13}$ and unchecked sexuality can turn mothers into monsters. Hence, the fun-loving Phoebe in Friends enters into motherhood in a nontraditional way, as a surrogate for her childishly naïve brother and his much older wife. In this same sitcom, Chandler Bing's parents represent the "monstrous consequences" of the sexual and gender freedom that feminism has long sought. Chandler's mother is depicted as a traditional sex object but also, because of her active and thus "out of control" sexual appetite, an absent mother. Chandler's father, moreover, is a drag queen, and there is something humorous, yet something sexist and scandalous, about the attractive and sultry

\footnotetext{
${ }^{12}$ After Diane leaves Sam at the altar in Cheers, she ends up in a mental asylum, where she meets Frasier Crane, whom she also later leaves at the altar. During the course of Seinfeld, moreover, Jerry never seriously asks Elaine to marry him, and in the series finale, Elaine is sentenced to a year in prison with her three male partners-in-crime, Jerry, George, and Kramer.

${ }^{13}$ Monica, one of the more traditional Friends, faces infertility issues in the final season of the show, although the sitcom makes clear in an evenhanded way that both she and husband Chandler are equally at "fault". Since the 19th century, however, American medical literature has linked "women's emancipation with their fertility status", and infertility is often couched in moral discussions as the "reproductive price of women's expanded freedoms” (Sandelowski, 1990: p. 476).
} 
Kathleen Turner playing a man playing a woman. Friends indicts Chandler's "improperly gendered" parents-a masculine mother and, thus, an emasculated father-as responsible for his neuroses, which marry nicely with wife Monica's obsessive, controlling demeanor (stemming from once having been fat, which in current American culture is equated with the monstrous). The ultimate example, however, is Carla from Cheers. As "one of the guys", this unmarried but permanently pregnant waitress pays a price, personally, for emulating the sexual promiscuity of her boss Sam Malone and, culturally, for joining the bar's patrons in harassing and bullying other women (particularly Diane Chambers and her successor Rebecca Howe). ${ }^{14}$ Carla, like Roseanne, bears little resemblance to a typical onscreen sex object. Instead, while raising her children as a working single mom, she is a misogynist who literally and figuratively serves men.

Women in today's sitcoms, defined by these newer, more masculine notions of femininity and maternity, threaten to end men's adventure and power. By casting and castigating TV females as anti-male/anti-female abominations, they make lousy role models for women and men (during what is supposed to be the "family hour") and ultimately reify patriarchal forms of viewing pleasure. ${ }^{15}$

Since the 2001-2002 season of Friends, publicly broadcast television has yet to produce a sitcom earning the highest Nielsen ratings, and some of this may be attributed to the rise of reality TV. Nonetheless, the notion of women/wives/mothers as fun-killers has thoroughly infiltrated the collective sitcom consciousness in the 21st century. Shows such as Everybody Loves Raymond, 'til Death, How I Met Your Mother, Gary Unmarried, and Two and a Half Men play upon this new tropewoman as man's worst enemy. ${ }^{16}$ From this perspective, the role

\footnotetext{
${ }^{14}$ Elaine from Seinfeld pays a similar price for being one of the guys - and not just with her incarceration in the series finale. In "The Soup Nazi", for example, she is banned from the Soup Nazi's restaurant for an entire year after vocally expressing her opinions in public about her soup likes and dislikes and impersonating Al Pacino's character from Scent of a Woman (complete with renditions of the lieutenant colonel's guttural "hoo-ahs"). She exacts her revenge, however, when she finds the Soup Nazi's recipes and threatens to expose his culinary secrets. Like the modern sitcom woman she is, her retaliation threatens to end her male pals' fun. As George explains: "Elaine's down there causing all kinds of commotion. Somehow she got a hold of his recipes and she says she's gonna drive him out of business. The Soup Nazi said that now that his recipes are out, he's not gonna make any more soup. He's moving out of the country, moving to Argentina! No more soup, Jerry! No more soup for any of us!" (Nov. 2 1995, episode 706).

${ }^{15}$ The 1971-1972 season finale of All in the Family, for example, launched the pilot episode of Maude, a sitcom about a brash, liberated matriarch who lives with her fourth husband, Walter, and her divorced daughter, Carol, a single mom ("Maude", March 11, 1972, episode 224). This episode centers around Carol's second wedding - an atypical affair where the mother of the bride and the bride-to-be cast marriage and even women in a poor light. As they discuss how many bridal showers each has thrown for the other, husbands and children emerge as the disposable objects of modern mothers and wives:
}

MAUDE: I eloped with your father and with Fred, not Albert.

CAROL: I threw you a shower, and it wasn't Albert.

MAUDE: Listen to me, in 12 years we have had three showers,

right? So that means you threw me either Albert or Walter because I

threw you Peter and David.

CAROL: I threw you Walter, but you did not throw me Peter and David, just David.

MAUDE: Four days before you married Peter I threw you a shower.

CAROL: Mother, that's impossible. Pete and I were living together. People thought we were already married.

MAUDE: [realizing their calculation mistake] That's it — it was a

baby shower. reversal in 60 years of popular television sitcoms has reversed neither of the visual dilemmas Mulvey identifies, except that the bearer of guilt is, like a monster, no longer funny. The sitcom narrative continues to revolve around masculine pleasure, and the woman/wife/mother is relegated to serving as either a sadistic obstacle to or a fetishistic object of this pleasure. Female characters openly acknowledged this in the 1970s and 1980s. In Three's Company, Janet abhors being the only responsible member of the household. "Reliable is dull and dull is boring and boring's no fun", she tells herself. To solve this problem, however, she and her sex-starved landlady, Mrs. Roper, decide to join a nude protest on a nearby beach. Apparently, modern women, to avoid being taken for granted and to recoup their humor and humanity, must turn themselves (back) into sex objects. As Janet notes, "Let's go down to that beach and prove that we're people, too" ("Good Old Reliable Janet", Sept. 19, 1978, episode 301). ${ }^{17}$

Other feminist theorists have argued for alternatives to Mulvey's framework for spectatorship or that the role of sex object bestows significant power to the woman. Mary Ann Doane (1991) suggests that a woman can view rather than be viewed by deliberately wearing a mask of femininity and assuming a destabilizing distance between herself and the images onscreen. This masquerade, Doane maintains, allows the woman to avoid both masochistically over-identifying with the female images and narcissistically becoming her "own object of desire", leaving her in a position to hide from the male gaze (by deflecting it onto the manufactured identity) and to manipulate the masquerade for her own gains (Doane, 1991). "[I]n flaunting femininity" and understanding womanliness as "a mask which can be worn or removed", female spectators can "disarticulat[e] male systems of viewing" (Doane, 1991: pp. 25-26). Carol J. Clover (1992) sees feminine visual pleasure in the "final girl" of horror films, where both male and female viewers identify with the last-standing heroine who overpowers the serial killer and ends the narrative threat. Doane's and Clover's roles, however, offer viewers fairly bleak options for feminine or maternal pleasure: hiding from the male gaze (as behind a veil) or successfully avoiding horrific murder (through a combination of wielding chastity and phallic weaponry).

Gaylyn Studlar (1988) and Camille Paglia (1990) claim that

\footnotetext{
${ }^{16}$ Characters in sitcoms about non-Caucasian families seem to fare a little better, at least in terms of gender portrayals. African-American sitcoms in the 1990s and beyond may not pigeonhole fathers as incompetent boobs to the same degree as their Caucasian counterparts, but future research is needed in this area. Unfortunately, since the turn of the millennium, there has been a decline in the number of African-American sitcoms and most are often relegated to Fox, CW (formerly UPN and WB), or cable networks (Moore, 2008; see also Gillespie, 2006). There are even fewer choices for Latino, Asian, and other viewers, and these programs do not seem to offer new forms of viewing pleasure, either. ABC's The George Lopez Show was one option, although its father figure is at times childish and disobedient and, based in part on Lopez's life, has a contentious relationship with an unloving mother. NBC's Will and Grace, moreover, which depicted nonheterosexual relationships and ranked in the top 20 during its run, portrayed Will, a gay man, as the responsible nag (who is repeatedly accused of being both fat and a girl) and Grace, a heterosexual woman, as the masculine, flat-chested, irresponsible slob.

${ }^{17}$ A similar theme about the nature of "fun" women also can be found in The Andy Griffith Show. So-called "fun girls" Skippy and Daphne, recurring bit characters who appear in similarly titled episodes such as "Fun Girls" (April 13, 1964, episode 427) and "The Arrest of the Fun Girls" (April 5, 1965, episode 528), create trouble for Sheriff Andy Taylor and Deputy Barney Fife, who must juggle the pleasurable advances of these two free-spirited women and the not-so-pleasurable dating demands of their steady girlfriends.
} 
female sexuality sometimes gets the upper hand, as in the case of the femme fatale (e.g., Marlene Dietrich in the 1930 film Morocco). We remain dubious of theories that rationalize or glorify the objectification of women. At best, the femme fatale suggests to the viewer that some obstacles, or in this case sex objects, cannot be overcome. In this A Bridge Too Far motif (or perhaps we should say, "A Woman Too Far"), the woman's power manifests as a sex object that resists the male narrative of conquest - a plot element necessary to maintain the suspense and realism of the masculine narrative of pleasure-while preserving the sadistic voyeurism of the femme spectacle. At worst, the femme fatale finds that only by playing the masculine role, as Dietrich does in Morocco when she puts on a man's top hat, ogles a woman in a bar, and then kisses her full on the lips, can she participate in the narrative of visual pleasure (Smelik, 1999).

\section{Capitalism}

The role reversal evident in America's top sitcoms has left intact the masculine visual pleasure described by Mulvey (woman/wife/mother as either perfect product or bearer of guilt), revealing the mysterious power of capital identified by Karl Marx that transcends superficial gender roles. As Marx notes in The Economic and Philosophical Manuscripts of 1844, money has the power to transform "fidelity into infidelity, love into hate, hate into love, virtue into vice, vice into virtue, servant into master, master into servant, idiocy into intelligence and intelligence into idiocy" (1964: p. 169). In other words, both power and the masculine narrative of visual pleasure do not reside with the man. "The major cultural apparatuses are not patriarchal, therefore, because they are dominated by men", art historian and feminist Griselda Pollock explains; "it is rather that they service masculine fantasies and needs in the conflicts that human subjectivity and its predominant forms of sexual difference generate" (1992a: p. 33). These "cultural apparatuses" include the structure of visual pleasure operative in television's most-popular sitcoms. For this reason, capital can turn the hierarchical relationship between men and women on its head without dismantling oppressive narratives that model the conditions of capitalist consumption. ${ }^{18}$

In reversing the roles of intellectual and idiot, women continue to bear the guilt and now also the responsibility of derailing male pleasure. Men, concomitantly, have been reduced to the intellectual equivalents of children, seeking gratification in games and toys (objects of consumption like power tools or women). When women attempt to escape their role as bearers of guilt and acquire pleasure, they must do so either by becoming "men" or turning themselves back into sex objects. Like The Cosby Show, Roseanne represented a small window of opportunity at the intersection of these role transitions in which

\footnotetext{
${ }^{18}$ The situational comedy, whether on the radio or television, is, in part, nothing more than a vehicle for advertising and, at times, an extended commercial in itself. See Landay (1999) for a discussion of I Love Lucy as a portrayal of America's mass consumer culture ideology and the "good life" understood as the acquisition of commodities. In fact, in "Never Do Business with Friends" (June 29, 1953, episode 67), Lucy begs Ricky for a new washing machine and, in turn, Lucy and Ethel convince Ricky to sell Fred the old washing machine. When the characters individually discover how valuable the used washing machine is, each couple surreptitiously attempts to sell the machine for a profit, regardless of the strife this causes in their relationships. I Love Lucy, in this episode and others, absolves our capitalist and consumerist priorities by hiding them behind a morality tale of friendship.
}

women might have maintained both the humor of Lucy and the maturity of Home Improvement's Jill. But in the end, comedienne Roseanne, who successfully doffs the shackles of sex object, must appropriate masculine behavior (grabbing her crotch on stage and generally representing "macho-feminist ferocity" [Stanley, 2008: p. 190]), thus repeating a patriarchal tendency that Pollock identifies in Degas' Woman with a Lorgnette (1866) and other similar paintings - " [t] $]$ he collapse of the feminine into the monstrous" (1992b: p. 106). So too with the third possibility in sitcoms: A funny feminism that offers a more dynamic view of woman/wife/mother stopped being funny. The fact that female stand-up pioneers such as Roseanne Barr and Joan Rivers "are now almost as well known for drastic cosmetic surgery as for comedy is either a cautionary tale or a very sad punch line" (Stanley, 2008: p. 190).

It seems the woman who wants to be fun and funny must return to the status of sex object. As Alessandra Stanley argues in an April 2008 issue of Vanity Fair, the television "industry demands that they [comedic women] keep growing prettier", an assertion bolstered by America's new funny girls: Sarah Silverman, Amy Poehler, Kristen Wiig, Maya Rudolph, and Tina Fey. "With television, it's just expected that every person be better-looking", admits Tina Fey when confronted with her own beauty (Stanley, 2008: p. 185). Poehler agrees: "For funny ladies, we're attractive" (Stanley, 2008: p. 190). This trend may help explain why the Parents Television Council (2007) continues to object to the overt sexuality of sitcoms aired during the family hour.

\section{Yearning "Beyond the Frame"}

While the proliferation of channels has provided room for alternative modes of visual expression, and no doubt some have succeeded, mainstream sitcoms have interpreted second and third wave feminism by portraying women with access to resources such as education, meaningful employment, and power —within as well as beyond the household - as "fun-killers". An increase in civil rights and participation in all forms of capital, then, has come at a price for television's woman, simultaneously demonized for encroaching into traditionally masculine roles and held responsible for the childish antics of their male counterparts.

Today's top-rated television sitcoms demonstrate a general failure to transcend oppressive forms of visual pleasure or produce a third possibility for feminine or maternal pleasure-a form of pleasure that might also threaten our culture of consumption maintained primarily through advertising. Though television sitcoms made a clear and distinct effort to transform the roles of women in the 1970s and 1980s, women in general and mothers in particular have been left to seek positive expressions of the feminine and maternal outside of the family hour. This is nothing new. Simple role reversals do not change the hierarchies of looking and pleasure. Pollock points out the woeful inadequacy of similar transformative efforts in art in the 1800s. Pollock finds that Mary Cassatt's proto-feminist Woman at the Opera (1879/1880), who gazes from her loge to the stage off-canvas, is merely left to yearn "beyond the frame" and is not much of an improvement over Degas' bug-eyed Woman with a Lorgnette (1866) and similar pieces. Moreover, Cassatt's "imageries of mother and child" such as Marie Looking Up at the Mother (1897) "are often embarrassingly dismissed, even by feminist critics, for banality and sentimentality" (Pollock, 
1992b: pp. 124-125). It is not surprising that second wave feminism continued this abjection of such maternal notions and instead opted to concentrate on sexual freedoms: Leaders of the second wave movement were predominantly middle-class Caucasian women who already enjoyed access to prenatal and obstetrical care (Ruzek, Clarke, \& Olesen, 1997). Moreover, focusing on the maternal risks essentialism-womanhood being equated with deterministic ideas that "woman's physical structure and the performance of maternal functions place her at a disadvantage" (and that "a proper discharge of her maternal functions" involves "not merely her own health, but the wellbeing of the race"), as the US Supreme Court case Muller $v$. Oregon (1908: pp. 421-422) concluded. Our six-decade review of America's highest-ranked sitcoms underscores the powerlessness of mainstream television to "conceive a new language of desire" (Mulvey, 1992: p. 748), leaving woman yearning, "suspecting that there is more than the social world envisages for her" (Pollock, 1992b: pp. 123-124).

\section{Acknowledgements}

The pilot project that forms the basis of this paper, written in April 2009, was funded by a 2006 Armstrong Atlantic State University faculty development award. Final revisions of the paper were completed as part of a Brocher Foundation visiting researcher residency in Hermance, Switzerland, in 2011. The authors also would like to thank all peer reviewers as well as several colleagues who have provided feedback on multiple versions of this manuscript.

\section{REFERENCES}

Bandura, A. (1977). Social learning theory. Englewood Cliffs, NJ: Prentice-Hall.

Buzzard, K. (2002). The Peoplemeter wars: A case study of technological innovation and diffusion in the ratings industry. Journal of Media Economics, 15, 273-291. doi:10.1207/S15327736ME1504 4

Clover, C. J. (1992). Men, women, and chain saws: Gender in the modern horror film. Princeton, NJ: Princeton University Press.

Doane, M. A. (1991). Femme fatales: Feminism, film theory, psychoanalysis. New York: Routledge.

Douglas, S. J. (1995). Where the girls are: Growing up female with the mass media. New York: Three Rivers Press.

Frazier, J. M., \& Frazer, T. C. (1993). "Father Knows Best" and "The Cosby Show": Nostalgia and the sitcom tradition. Journal of Popular Culture, 27, 163-172. doi:10.1111/j.0022-3840.1993.00163.X'

Friedan, B. (1997). The feminine mystique. New York: W.W. Norton \& Company.

Gillespie, F. (2006). Major networks black out African American comedies. Crisis, 113, 57-58.

Glaser, B. G. (1978). Theoretical sensitivity: Advances in the methodology of grounded theory. Mill Valley, CA: Sociology Press.

Glaser, B. G., \& Strauss, A. L. (1967). The discovery of grounded theory: Strategies for qualitative research. Chicago, IL: Aldine Transaction.

Griffin, E. (2003). A first look at communication theory (5th ed.). Boston, MA: McGraw-Hill.

Horsburgh, S., \& Wihlborg, U. (2002). Moxie lady. People, 58, 105.

Landay, L. (1999). Millions "Love Lucy": Commodification and the Lucy phenomenon. NWSA Journal, 11, 25-47. doi:10.1353/nwsa.1999.0013

Marx, K. (1964). Economic and philosophical manuscripts of 1844. In D. J. Struik (Ed.), \& M. Milligan (Trans.), New York: International Publishers.

McEachern, C. (1999). Comic interventions: Passion and the men's movement in the situation comedy, Home Improvement. Journal of
Gender Studies, 8, 5-18. doi:10.1080/095892399102788

McNeil, A. (1996). Total television: The comprehensive guide to programming from 1948 to the present (4th ed.). New York: Penguin Books.

Moore, M. L. (2008). The demise of the black sitcom. Starpulse Entertainment News Blog. URL

http://www.starpulse.com/news/index.php/2008/08/13/the_demise_o f the black sitcom

Mulvey, L. (1992). Visual pleasure and narrative cinema. In G. Mast, M. Cohen, \& L. Braudy (Eds.), Film theory and criticism: Introductory readings (pp. 746-757). New York: Oxford University Press.

Napoli, P. M. (2005). Audience measurement and media policy: Audience economics, the diversity principle, and the local People Meter. Communication Law \& Policy, 10, 349-382. doi:10.1207/s15326926clp1004 1

Nielsen Media Research (n.d.). Measuring through representative samples. URL

http://www.nielsenmedia.com/ethnicmeasure/sampling.html

Nielsen Media Research (2007). Prime time top 20 programs [Data file]. The Nielsen Company Web Site, URL

http://www.nielsenmedia.com

Paglia, C. (1990). Sexual personae: Art and decadence from Nefertiti to Emily Dickinson. New Haven, CT: Yale University Press.

Parents Television Council (2007). The alarming Family Hour... no place for children: A content analysis of sex, foul language and violence during network television's Family Hour (executive summary). URL

http://www.parentstv.org/ptc/publications/reports/familyhour/family hour-92007-finalPDF.pdf

Pollock, G. (1992a). Degas/images/women; women/Degas/images: What difference does feminism make to art history? In R. Kendall, \& G. Pollock (Eds.), Dealing with Degas: Representations of women and the politics of vision (pp. 22-39). New York: Universe.

Pollock, G. (1992b). The gaze and the look: Women with binocularsA question of difference. In R. Kendall, \& G. Pollock (Eds.), Dealing with Degas: Representations of women and the politics of vision (pp. 106-130). New York: Universe.

Poniewozik, J. (2002). Color crosses over. Time, 159, 64.

Porter, M. J., Larson, D. L., Harthcock, A., \& Nellis, K. B. (2002). Redefining narrative events: Examining television narrative structure. Journal of Popular Film and Television, 30, 23-30. doi: $10.1080 / 01956050209605556$

Prior, M. (2009). The immensely inflated news audience: Assessing bias in self-reported news exposure. Public Opinion Quarterly, 73 , 130-143. doi:10.1093/poq/nfp002

Ruzek, S. B., Clarke, A. E., \& Olesen, V. L. (1997). Social, biomedical, and feminist models of women's health. In S. B. Ruzek, V. L. Olesen, \& A. E. Clarke (Eds.), Women's health: Complexities and differences (pp. 11-28). Columbus: Ohio State University Press.

Sandelowski, M. J. (1990). Failures of volition: Female agency and infertility in historical perspective. Signs: Journal of Women in Culture and Society, 15, 475-499. doi:10.1086/494606

Smelik, A. (1999). Feminist film theory. In P. Cook, \& M. Bernink (Eds.), The cinema book (pp. 353-365). London: British Film Institute.

Stoddard Jr., L. (1987). The history of People Meters: How we got to where we are (and why). Journal of Advertising Research, 27, RC$10-\mathrm{RC}-12$.

Strauss, A. L., \& Corbin, J. M. (1998). Basics of qualitative research: Techniques and procedures for developing grounded theory (2nd ed.). Thousand Oaks, CA: Sage.

Stanley, A. (2008). Who says women aren't funny? Vanity Fair, 251, 182-191.

Studlar, G. (1988). In the realm of pleasure: Von Sternberg, Dietrich, and the masochistic aesthetic. Urbana and Chicago, IL: University of Illinois Press.

US Supreme Court (1908). Muller v. Oregon (208 US 412). Washington, DC.

Wood, J. (1962). Leaders in marketing: Arthur C. Nielsen. Journal of Marketing, 26, 77-78. doi:10.2307/1248309 